\title{
Response of Three Sugar Cane Varieties to Phosphorus Bio Fertilization
}

\author{
A. Z. Ahmed \\ Sugar Crops Research Institute, Agriculturla Research Center, Giza, Egypt.
}

\begin{abstract}
TOWADAYS, there is a call for the reduction of the environmental pollution resulted 1 from over application of chemical fertilizers. Therefore, research has been done to investigate the possibility and efficiency of using bio fertilizers. This work was carried out at El-Mattana Agricultural Research Station (latitude of $25.17^{\circ} \mathrm{N}$ and longitude $32.33^{\circ} \mathrm{E}$ ), Luxor Governorate, Upper Egypt during 2011-2012 season (plant cane crop) and 20122013 season (first ratoon crop) to study the effect of different levels of P- bio fertilizer (200, 400 and $600 \mathrm{~g} \mathrm{P}$ - bio fertilizers /fad) on yield, yield components and quality of three sugarcane varieties (G.T.54-9, G.98-28 and G.99-103). P- bio fertilizer comprises an effective dissolvers strain of phosphate Bacillus megatherium var. Egyptiacum. Randomized complete block design with four replications arranged in split- plots system was used.
\end{abstract}

The results indicated that the examined sugarcane varieties differed significantly. Promising varieties G.99-103 recorded the highest values of number of millable cane / $\mathrm{m}^{2}$, millable cane height, diameter and cane yield, while G.T. 54-9 surpassed in respect to Brix, sucrose, sugar recovery percentages and sugar yield in plant cane and its ratoon crops. Increasing P-bio fertilizer levels up to $600 \mathrm{~g} / \mathrm{fad}$ significantly increased in number of millable cane $/ \mathrm{m}^{2}$, millable cane height, diameter, Brix $\%$ sucrose $\%$, sugar recovery $\%$, cane and sugar yields in plant cane and its ratoon crops.

It could be concluded that under the conditions of the present work, it is recommended to inoculate G.99-103 or G.T 54-9 sugarcane varieties cuttings by 600 g P-bio fertilizer/ fad to produce the highest cane, sugar yield, as well as decrease the environmental pollution.

Keywords: P-bio fertilizer, Sugar cane, Bio fertilizers.

\section{Introduction}

Sugar cane (Saccharum officinarum L.) is one of the crops that need to many amounts of nutrients especially phosphorus element. So, it is better to use another substances give the nutrients for growing the plants and decrease the environmental pollution. Bio-fertilizers are part of the substances that decrease the environmental pollution, provide considerable amounts of the plant's phosphorus requirement, promote rooting and improve sugarcane growth by direct effects on metabolic processes, in addition to their role in phosphorus solubilizing. Bio-fertilizers also had an important role in the utilization of phosphorus by sugar cane through higher biological phosphorus solubilizing and increasing the availability and uptake of phosphorus.

The environmental and economic advantages of bio-fertilizers in sugar cane phosphorus nutrition were reported by Kumaraswamy \& Rajasekaran (1994), Muthukumaraswamy et al. (1994), Premono et al. (1995), Ismail et al. (2000), Shankaraiah et al. (2000), Sundara et al. (2001), Osman et al. (2004) and Ahmed (2013).

The role of sugar cane variety is considered the corner stone or the main factor in governing

"Corresponding author email: ahmedazarc@yahoo.com 
the expected sugar yield. It is well known that the commercial variety G.T. 54-9 occupies most of sugar cane area planted in Egypt. Recently, Sugar Crops Research Institute produced some promising varieties of sugarcane among them G.98-28 and G.99-103. Many studies were carried out to select among the produced varieties in yield and its components, as well as, juice quality parameters among them Rizk et. al. (2004), ElShafai \& Ismail (2006), El-Labbody et al. (2011), Mohamed et al. (2012), Yousif et al. (2015) and Ahmed et al. (2016).

The objective of this study was to evaluate the productivity of three sugar cane varieties under varying Phosphatic bio-fertilizers level to determine the optimum Phosphatic bio-fertilizers for each variety and decrease the environmental pollution by chemical fertilizers.

\section{Materials and Methods}

The present study was conducted at EL-Mattana Agricultural Research Station, (latitude of $25.17^{\circ}$ $\mathrm{N}$ and longitude $32.33^{\circ} \mathrm{E}$ ), Luxor Governorate, Upper Egypt during during 2011-2012 season (plant crop) and 2012-2013 season (first ratoon crop) This work included nine treatments represent the combinations between three levels of P- bio fertilizer $(200,400$ and $600 \mathrm{~g} / \mathrm{fad})$ and three sugarcane varieties (G.T. 54-9 as a commercial variety , G. $98-28$ and G. $99-103$ as promising varieties). P- bio fertilizer /fad was used at the rate of $0.5,1.0$ and $1.5 \mathrm{bag} / \mathrm{fad}$, (one bag $=400 \mathrm{~g}$ ) which contains 107-109 microbes approximately. P-bio fertilizer comprises an effective dissolvers strain of phosphate Bacillus megatherium var. Egyptiacum. It was mixed with appropriate amount of fine sand and applied manually onsugar cane seeds in furrows for plant cane, irrigation was immediately practiced. In the first ratoon, the bio-fertilizer was applied with the first irrigation. The P-bio source was brought from the General Organization for Agricultural Equalization Fund (G O A E F), Agricultural Research Center, Giza.

A Randomized complete block with four replications arranged in split-plot design was used. Sugar cane varieties were allocated to the main plots, while P- bio fertilizer levels treatments were randomly distributed in the sub-plots.

Plot area was $35 \mathrm{~m}^{2}$ containing five rows, the length of each row is seven meters, while row width was one meter. The dry method of planting was adopted using two row (drill) of cane cuttings. Planting took place in the $2^{\text {nd }}$ week of March, 2011 while harvest was done in the $3^{\text {rd }}$ week of March 2012 and 2013 in the $1^{\text {st }}$ and $2^{\text {nd }}$ seasons, respectively. All the other cultural practices were carried out as recommended in the region. The mechanical and chemical analysis of soil of the experimental sit showed that soil was clay loam, containing $61 \mathrm{ppm}$ available nitrogen, $10 \mathrm{ppm} \mathrm{P}$ and $40 \mathrm{ppm} \mathrm{K}$ and $\mathrm{PH}$ of 7.7.

\section{Data recorded}

The following data were recorded at harvest:

\section{Yield and yield components}

1. Number of millable cane $/ \mathrm{m}^{2}$.

2. Millable cane length $(\mathrm{cm})$ was measured from land level up to the top visible dewlap.

3. Millable cane diameter $(\mathrm{cm})$ was measured at the middle part of stalks.

4. Cane yield (Tons/fad). The millable cane of three guarded rows of each sub plots were harvested, topped, cleaned, weighed and cane yield (tons/fad) was calculated.

\section{Juice quality}

A sample of 25 millable cane from each subplot were chosen immediately after harvest, cleaned and crushed through mill and juice was analyzed to determine the following parameters:

1. Brix percentage (Total soluble solids, TSS $\%$ ) in juice was determined using Brix Hydrometer according to A.O.A.C. (1995).

2. Sucrose percentage was determined using Saccharemeter according to A.O.A.C. (1995).

3. Sugar recovery percentage was calculated according to the following formula described by Yadav \& Sharma (1980).

Sugar recovery percentage $=[$ Sucrose $\%-$ $0.4($ brix $\%$ - sucrose $\%$ )] x 0.73

where: 0.4 = each pound of non-sucrose solids in the juice will retain 0.4 of a pound of sucrose as outlined by Hebert (1973).

$0.73=$ denote to a correction factor for actual milling 
condition in factories that depends on the overall mean fiber percentage cane during processing as outlined by Mathur (1997).

\section{Sugar yield}

Sugar yield (tons/fad)was calculated according to the following formula described by Mathur (1997).

$$
\begin{gathered}
\text { Sugar yield }=\text { cane yield (tons } / \text { fad) } x \text { sugar } \\
\text { recovery percentage. }
\end{gathered}
$$

All recorded data were statistically analyzed according to the method of Snedecor \& Cochran (1981). Treatment means were compared using LSD at $5 \%$ level of significance as outlined by Steel \& Torrie (1980).

\section{$\underline{\text { Results and Discussion }}$}

\section{Number of millable cane $/ \mathrm{m}^{2}$}

Data in Table 1 showed that the evaluated sugar cane cvs. differed significantly in the number of millable cane per square meter in both seasons. The highest number of millable cane/ $\mathrm{m}^{2}$ was produced by $\mathrm{G} 99-103$ variety (7.59 and 10.04), while the lowest number was obtained from G98-28 variety (6.93 and 8.82) in plant cane and first ratoon crops, respectively. This result may reflect the capacity of G99-103 variety to produce more survival tillers at harvest time compared to other two varieties. Similar result was obtained by Rizk et. al. (2004), El-Shafai, \& Ismail (2006) and Yousif et al. (2015) who found significant differences among tested sugar cane varieties in number of millable cane $/ \mathrm{m}^{2}$.

Results given in the same Table increasing P-bio fertilizers level from 200 to $600 \mathrm{~g} / \mathrm{fad}$ was accompanied by significant increase in the number of millable cane $/ \mathrm{m}^{2}$ in the plant and the its ratoon crop. This result may be due to the role of phosphorus in meristemic activity of plant tissues and shoot. These results are similar with those obtained by Ismail et al. (2000) and Sundara et al. (2001) they reported that phosphate solubilizing bacteria (PSB) application enhanced tailoring and stalk population.

\begin{tabular}{|c|c|c|c|c|c|c|c|c|}
\hline \multirow{3}{*}{$\begin{array}{l}\begin{array}{l}\text { Bio-P } \\
\text { fertilizer }\end{array} \\
\text { g/fad }\end{array}$} & \multicolumn{4}{|c|}{ 2011/2012 Plant crop } & \multicolumn{4}{|c|}{ 2012/2013 First ratoon crop } \\
\hline & \multicolumn{3}{|c|}{ Varieties } & \multirow[b]{2}{*}{ Mean } & \multicolumn{3}{|c|}{ Varieties } & \multirow[b]{2}{*}{ Mean } \\
\hline & $\begin{array}{c}\text { GT } \\
54-9\end{array}$ & G98-28 & $\begin{array}{c}\text { G99- } \\
103\end{array}$ & & GT 54-9 & G98-28 & $\begin{array}{c}\text { G99- } \\
103\end{array}$ & \\
\hline 200 & 86.5 & 6.00 & 6.59 & 6.39 & 8.00 & 8.63 & 8.70 & 8.44 \\
\hline 400 & 7.36 & 6.80 & 7.68 & 7.28 & 9.37 & 8.74 & 10.43 & 9.51 \\
\hline 600 & 7.99 & 7.99 & 8.50 & 8.16 & 10.37 & 9.09 & 11.00 & 10.24 \\
\hline Mean & 7.31 & 6.93 & 7.59 & & 9.25 & 8.82 & 10.04 & \\
\hline \multicolumn{9}{|l|}{ L S D 5\% for: } \\
\hline Varieties (V) & & & 0.29 & & & & & 0.33 \\
\hline P-bio fertilizer $(\mathrm{P})$ & & & 0.80 & & & & & 0.86 \\
\hline$(\mathrm{V}) \mathrm{x}(\mathrm{P})$ & & & 1.68 & & & & & 1.81 \\
\hline
\end{tabular}

TABLE 1. Number of millable canes $/ \mathrm{m}^{2}$ of the three sugarcane varieties as affected by P-bio levels.

Data in the same table revealed that number of millable cane $/ \mathrm{m}^{2}$ was significantly affected by the interaction between the two studied factors. It is clear from the data in both seasons that the tested varieties respond to the increase in P-bio fertilizer rate. It could be noted that G99-103 promising variety recorded the highest millable cane number (8.50 and 11.00) in both cane and ratoon crops respectively, with $600 \mathrm{~g} /$ fad of phosphorus bio- fertilizers.

\section{Millable cane height}

Results in Table 2 showed that the tested sugar cane varieties differed significantly in millable cane height in both seasons. Variety G.99-103 gave the tallest millable cane (288 and 300). While G.98-28 variety gave the shortest millable cane (246 and 261) in first and second seasons, respectively. This result may be due to the genetic differences among varieties in their ability of the formation of internodes and/or determination of 
their length. This result is in accordance with those reported by El-Shafai, \& Ismail (2006), ElLabbody et al. (2011) and Yousif et al. (2015) who found that the tested varieties significantly differed in stalk height.

TABLE 2.Millable cane height $(\mathrm{cm})$ of the three sugarcane varieties as affected by $\mathbf{P}$-bio levels.

\begin{tabular}{|c|c|c|c|c|c|c|c|c|}
\hline \multirow{3}{*}{$\begin{array}{l}\text { Bio-P } \\
\text { fertilizer } \\
\text { g/fad }\end{array}$} & \multicolumn{4}{|c|}{ Plant crop (2011/2012) } & \multicolumn{4}{|c|}{ First ratoon crop $(2012 / 2013)$} \\
\hline & \multicolumn{3}{|c|}{ Varieties } & \multirow{2}{*}{ Mean } & \multicolumn{3}{|c|}{ Varieties } & \multirow{2}{*}{ Mean } \\
\hline & $\begin{array}{c}\text { GT } \\
54-9\end{array}$ & $\begin{array}{c}\text { G98- } \\
28\end{array}$ & $\begin{array}{c}\text { G99- } \\
103\end{array}$ & & GT 54-9 & G98-28 & $\begin{array}{c}\text { G99- } \\
103\end{array}$ & \\
\hline 200 & 238 & 232 & 256 & 242 & 258 & 238 & 271. & 256. \\
\hline 400 & 252 & 240 & 272 & 255 & 269 & 251 & 299 & 273 \\
\hline 600 & 302 & 267 & 337 & 302 & 302 & 290 & 331 & 308 \\
\hline Mean & 264 & 246 & 288 & & 275 & 261 & 300 & \\
\hline \multicolumn{9}{|l|}{ L S D 5\% for: } \\
\hline Varieties (V) & & & 10.6 & & & & & 9.1 \\
\hline P-bio fertilizer (B) & & & 15.8 & & & & & 10.8 \\
\hline (V) $\mathrm{x}(\mathrm{P})$ & & & 21.9 & & & & & 19.9 \\
\hline
\end{tabular}

The results given in the same table revealed that increasing P-bio fertilizer from 200 to 400 and $600 \mathrm{~g} / \mathrm{fad}$ led to a significant and gradual increasing in millable cane height in the $1^{\text {st }}$ and $2^{\text {nd }}$ growing seasons. This result could be due to the production of Phytohormones substances resulted from microbial activity in root zone which may be enhanced growth of cane plants. These results are in harmony with those obtained by Ismail et al. (2000) and Osman et al. (2004) they noted that sugar cane P- bio fertilizers treatments affected significantly stalk height.

Interaction between tested sugar cane varieties and bio-P fertilizer had a significant effect on the millable cane height in both seasons. Generally the tallest millable cane $(337$ and $331 \mathrm{~cm}$ ) were obtained from planting G.99-103 variety with $600 \mathrm{~g}$ bio-P fertilizer /fad in $1^{\text {st }}$ and $2^{\text {nd }}$ seasons, respectively.

\section{Millable cane diameter}

The results in Table 3 showed that sugar cane varieties significantly in millable cane diameter in the $1^{\text {st }}$ and $2^{\text {nd }}$ seasons. Sugarcane variety G99103 recorded the thickest millable cane (3.33and 3.18) followed by G.T.54-9 (3.11and 2.96). While G.98-28 variety had the lowest value (2.79 and 2.73) of this trait, respectively. The superiority of G99-103 variety in millable cane diameter may be controlled by genetic make-up. Significant differences among cane varieties in this trait were also reported by El-Shafai, \& Ismail (2006), Mohamed et al. (2012) and Yousif et al. (2015) they obtained significant differences among studied varieties in stalk diameter. revealed that sugar cane varieties differed significantly in millable cane diameter.

It could be noted that applied P-bio fertilizer levels had a significant effect on millable cane diameter. also data cleared that increasing P-bio fertilizer level from 200 to $600 \mathrm{~g} /$ fad significantly and gradual increased the millable cane diameter and the highest value (3.21 and 3.17) was recorded when plants received $600 \mathrm{~g} / \mathrm{fed}$. in the two seasons, respectively. This result may be due to the role of phosphorus is required more by meristic activity of plant tissues and shoot phosphorus concentration declines with age. This result is in agreement with that found by Premono et al. (1995), Shankaraiah et al. (1995) and Ahmed (2013) who found that increasing P- bio fertilizer level from zero to $800 \mathrm{~g} /$ fad resulted in a significant increase in millable cane diameter.

Also, data showed that millable cane diameter significantly responded to the interaction between factors. In $1^{\text {st }}$ and $2^{\text {nd }}$ seasons promising sugar cane variety G.99/103 recorded the thickest millable cane (3.43 and 3.31) when fertilized with $600 \mathrm{~g}$ Phosphobacterin/fed in the $1^{\text {st }}$ and $2^{\text {nd }}$ seasons, respectively. 
TABLE 3. Millable cane diameter $(\mathrm{cm})$ of the three sugarcane varieties as affected by $\mathbf{P}$-bio levels.

\begin{tabular}{|c|c|c|c|c|c|c|c|c|}
\hline \multirow{3}{*}{$\begin{array}{l}\text { Bio-P } \\
\text { fertilizer } \\
\text { g/fad }\end{array}$} & \multirow{2}{*}{\multicolumn{3}{|c|}{$\begin{array}{l}\text { Plant crop }(2011 / 2012) \\
\text { Varieties }\end{array}$}} & & \multicolumn{4}{|c|}{ First ratoon crop $(2012 / 2013)$} \\
\hline & & & & & \multicolumn{3}{|c|}{ Varieties } & \multirow[b]{2}{*}{ Mean } \\
\hline & GT 54-9 & $\begin{array}{c}\text { G98- } \\
28\end{array}$ & G99-103 & & GT 54-9 & $\begin{array}{c}\text { G98- } \\
28\end{array}$ & $\begin{array}{c}\text { G99- } \\
103\end{array}$ & \\
\hline 200 & 3.06 & 2.60 & 3.20 & 2.95 & 2.68 & 200 & 3.00 & 2.74 \\
\hline 400 & 3.11 & 2.75 & 3.35 & 3.07 & 3.01 & 400 & 3.22 & 2.98 \\
\hline 600 & 3.16 & 3.03 & 3.43 & 3.21 & 3.19 & 600 & 3.31 & 3.17 \\
\hline Mean & 3.11 & 2.79 & 3.33 & & 2.96 & 2.73 & 3.18 & \\
\hline \multicolumn{9}{|l|}{ L S D 5\% for: } \\
\hline Varieties (V) & & & 0.22 & & & & & 0.17 \\
\hline P-bio fertilizer (B) & & & 0.19 & & & & & 0.16 \\
\hline$(\mathrm{V}) \mathrm{x}(\mathrm{P})$ & & & 0.40 & & & & & 0.34 \\
\hline
\end{tabular}

Cane yield

Data presented in Table 4 revealed that the examined sugarcane varieties differed significantly in cane yield in both the plant cane and first ratoon crops. Promising variety G.99-103 out yielded the two commercial varieties G.T.54-9, and G.9828 by 5.64 and $15.33 \%$, respectively, in the plant cane, and by 5.95 and $18.13 \%$, respectively, in the first ratoon. These results could be attributed to their superiority in number of millable canes/ $\mathrm{m}^{2}$, millable canes height and diameter (Tables 1, 2 and 3). Differences in cane yield among genotypes were also found by El-Shafai \& Ismail (2006) and Yousif et al. (2015) they found that tested sugar cane varieties differed significantly in cane yield significant differences among the tested sugar cane varieties in cane yield.

TABLE 4. Cane yield tons/fad of the three sugarcane varieties as affected by $P$-bio levels.

\begin{tabular}{|c|c|c|c|c|c|c|c|c|}
\hline \multirow{3}{*}{$\begin{array}{l}\begin{array}{l}\text { Bio-P } \\
\text { fertilizer }\end{array} \\
\text { g/fad }\end{array}$} & \multicolumn{4}{|c|}{ Plant crop (2011/2012) } & \multicolumn{4}{|c|}{ First ratoon crop $(2012 / 2013)$} \\
\hline & \multicolumn{3}{|c|}{ Varieties } & \multirow[b]{2}{*}{ Mean } & \multicolumn{3}{|c|}{ Varieties } & \multirow[b]{2}{*}{ Mean } \\
\hline & $\begin{array}{l}\text { G.T. } \\
54-9\end{array}$ & $\begin{array}{c}\text { G.98- } \\
28 \\
\end{array}$ & $\begin{array}{c}\text { G.99- } \\
103 \\
\end{array}$ & & G.T. 54-9 & $\begin{array}{c}\text { G.98- } \\
28 \\
\end{array}$ & $\begin{array}{c}\text { G.99- } \\
103\end{array}$ & \\
\hline 200 & 26.10 & 23.70 & 28.66 & 26.15 & 37.90 & 33.17 & 39.87 & 36.98 \\
\hline 400 & 30.50 & 26.08 & 30.67 & 30.08 & 38.33 & 36.10 & 42.23 & 38.89 \\
\hline 600 & 33.33 & 32.61 & 35.68 & 33.87 & 43.70 & 38.30 & 44.97 & 42.32 \\
\hline Mean & 29.98 & 27.46 & 31.67 & & 39.98 & 35.86 & 42.36 & \\
\hline \multicolumn{9}{|l|}{ L S D 5\% for: } \\
\hline Varieties (V) & & & 1.09 & & & & & 1.23 \\
\hline $\begin{array}{l}\text { P-biofertilizer }(\mathrm{P}) \\
(\mathrm{V}) \mathrm{x}(\mathrm{P})\end{array}$ & & & $\begin{array}{l}1.40 \\
2.41\end{array}$ & & & & & $\begin{array}{l}1.41 \\
2.43\end{array}$ \\
\hline
\end{tabular}

Cane yield was significantly affected by the applied P-bio fertilizers levels. Data revealed that applying $600 \mathrm{~g}$ P-bio fertilizer/fad to sugar cane increased cane yield by 7.72 and 3.79 tons/fad, in the $1^{\text {st }}$ season, corresponding to 5.34 and 3.49 tons/fad, in the $2^{\text {nd }}$ one, compensate with 200 and $400 \mathrm{~g}$ P-bio fertilizer/fad, respectively. These results may be due to the essential favorable effect of phosphorus on the vegetative growth and tillering capacity of sugar cane plants. These results are in harmony with those mentioned by Kumaraswamy \& Rajasekaran(1994), Muthukumaraswamy et al. (1994) and Ahmed
(2013) who found that the applied P-bio fertilizers had a significant effect on cane yield in the two seasons.

Cane yields of the plant cane and the $1^{\text {st }}$ ratoon crops were significantly influenced by the interaction between sugarcane varieties and bio $\mathrm{P}$-fertilizer levels with a general trend of increase with different magnitudes, as bio $\mathrm{P}$-fertilizer level was increased. In general, the maximum values of cane yields (35.87 and 44.97 ton/fad) were obtained from G.99103 variety when it received $600 \mathrm{~g} / \mathrm{fad}$, in plant cane and first ratoon crops, respectively. 


\section{Brix percentage}

Data in Table 5 revealed that Brix percentage was significantly affected by the examined sugar cane varieties in the plant cane and the $1^{\text {st }}$ ratoon crops. These results may be due to differences in growth and their reaction to recorded among the studied cane varieties. It was found that G.T. 54-9 variety gave the highest Brix values (20.74 and $21.44 \%$ ) in first and second season, the surrounding environmental conditions prevailing during maturity development of soluble solids in plants. These results are in harmony with those reported by Rizk et. al.(2004) Mohamed et al. (2012) and Ahmed et al. (2016) who found that differences in Brix\% among sugar cane varieties.

Results showed that increasing P-bio fertilizer levels up to $600 \mathrm{~g} / \mathrm{fad}$ significantly increased the values of Brix percentage in first and second seasons. This results may be the fact that phosphorus increases the vegetative growth of plants and consequently resulted in more metabolites required for the formation of soluble solids. The effective role of P-bio fertilizer levels on Brix percentage has been reported by Sundara, et al. (2001) who found that P-bio fertilizer levels significantly affected Brix.

TABLE 5. Brix percentage of the three sugarcane varieties as affected by $\mathbf{P}$-bio levels.

\begin{tabular}{|c|c|c|c|c|c|c|c|c|}
\hline \multirow{3}{*}{$\begin{array}{l}\text { Bio-P } \\
\text { fertilizer } \\
\text { g/fad }\end{array}$} & \multirow{2}{*}{\multicolumn{3}{|c|}{$\begin{array}{l}\text { Plant crop (2011/2012) } \\
\text { Varieties }\end{array}$}} & \multirow[b]{3}{*}{ Mean } & \multicolumn{4}{|c|}{ First ratoon crop $(2012 / 2013)$} \\
\hline & & & & & \multicolumn{3}{|c|}{ Varieties } & \multirow[b]{2}{*}{ Mean } \\
\hline & $\begin{array}{c}\text { GT } \\
54-9\end{array}$ & G98-28 & G99-103 & & GT 54-9 & $\begin{array}{c}\text { G98- } \\
28 \\
\end{array}$ & $\begin{array}{c}\text { G99- } \\
103\end{array}$ & \\
\hline 200 & 19.79 & 19.29 & 19.66 & 19.58 & 21.12 & 20.81 & 20.44 & 20.79 \\
\hline 400 & 20.69 & 19.60 & 20.50 & 20.33 & 21.70 & 21.09 & 20.59 & 21.13 \\
\hline 600 & 21.75 & 20.87 & 21.25 & 21.29 & 21.98 & 21.65 & 20.90 & 21.51 \\
\hline Mean & 20.74 & 19.90 & 20.47 & & 21.44 & 21.18 & 20.64 & \\
\hline \multicolumn{9}{|l|}{ L S D 5\% for: } \\
\hline Varieties (V) & & & 0.31 & & & & & 0.39 \\
\hline \multicolumn{2}{|c|}{ P-biofertilizer (B) } & & 0.17 & & & & & 0.21 \\
\hline (V) $\mathrm{x}(\mathrm{P})$ & & & 1.29 & & & & & 1.46 \\
\hline
\end{tabular}

A speculative view to the interaction effect between two studied factors was significant. Increasing P-bio fertilizer levels up to $600 \mathrm{~g} /$ fad for G.T. 54 - 9 variety caused the greatest increasing in Brix percentage in both seasons.

\section{Sucrose percentage}

Data presented in Table 6 indicate that the evaluated cane varieties differed significantly in sucrose percentage in the plant and first ratoon crops. Sugar cane G.T.54-9 variety recorded the highest value of this trait (16.94 and 17.14) in the plant cane and first ratoon crops, respectively. The differences among the studied varieties in sucrose percentage are mainly due to their gene make-up. These results are in agreement with these obtained by El-Shafai \& Ismail (2006), El-Labbody et al. (2011) and Ahmed et al. (2016) who found that sucrose values broadly and significantly differed among the tested sugar cane varieties.
Also the data cleared that the effect of P-bio fertilizer levels on sucrose percentage was significant in first and second seasons. Highest values $(17.26 \%$ and $17.22 \%)$ were recorded when plants received $600 \mathrm{~g} / \mathrm{fad}$ in the cane and first ratoon crops, respectively. These results was in harmony with those obtained by Kumaraswamy \& Rajasekaran (1994) who found that bio-fertilization with phosphorn significantly increased sucrose $\%$.

The results revealed that sucrose percentage was significantly affected by the interactions between P-bio fertilizers and sugarcane varieties in the. In general Sugar cane variety of G.T.54-9 received 600 g P-bio fertilizer/ fad produced the highest sucrose percentage (17.89 and 18.12) in the $1^{\text {st }}$ and $2^{\text {nd }}$ seasons, respectively. 
TABLE 6. Sucrose percentage of the three sugarcane varieties as affected by $\mathbf{P}$-bio levels.

\begin{tabular}{|c|c|c|c|c|c|c|c|c|}
\hline \multirow{3}{*}{$\begin{array}{l}\text { Bio-P } \\
\text { fertilizer } \\
\text { g/fad }\end{array}$} & \multicolumn{4}{|c|}{ Plant crop (2011/2012) } & \multicolumn{4}{|c|}{ First ratoon crop $(2012 / 2013)$} \\
\hline & \multicolumn{3}{|c|}{ Varieties } & \multirow{2}{*}{ Mean } & \multicolumn{3}{|c|}{ Varieties } & \multirow{2}{*}{ Mean } \\
\hline & $\begin{array}{c}\text { GT } \\
54-9\end{array}$ & G98-28 & G99-103 & & GT 54-9 & $\begin{array}{c}\text { G98- } \\
28 \\
\end{array}$ & $\begin{array}{c}\text { G99- } \\
103 \\
\end{array}$ & \\
\hline 200 & 16.13 & 16.08 & 15.80 & 16.00 & 16.51 & 16.42 & 15.74 & 16.22 \\
\hline 400 & 16.81 & 16.15 & 16.58 & 16.51 & 16.79 & 16.58 & 16.16 & 16.51 \\
\hline 600 & 17.89 & 16.84 & 17.04 & 17.26 & 18.12 & 17.03 & 16.50 & 17.22 \\
\hline Mean & 16.94 & 16.36 & 16.47 & & 17.14 & 16.68 & 16.13 & \\
\hline \multicolumn{9}{|l|}{ L S D 5\% for: } \\
\hline Varieties (V) & & & 0.42 & & & & & 0.46 \\
\hline P-biofertilizer $(\mathrm{P})$ & & & 0.30 & & & & & 0.30 \\
\hline$(\mathrm{V}) \mathrm{x}(\mathrm{P})$ & & & 0.88 & & & & & 0.91 \\
\hline
\end{tabular}

Sugar Recovery percentage

Data collected in Table 7 pointed out that sugar recovery percentage was markedly affected by tested sugarcane varieties. Sugar cane variety G.T.54-9 surpassed the other varieties in sugar recovery percentage $(11.26 \%)$ followed by G.98$28(10.90 \%)$ in plant cane crops, while in the ratoon crop, G.T.54-9 variety recorded the highest value percentage $(11.21 \%)$ followed by G.98-28 variety $(10.85 \%)$. This result may be due variation in genetic structure among tested sugar cane varieties These results are in agreement with those of Rizk et. al.(2004), El-Shafai \& Ismail (2006) Mohamed et al. (2012) and Ahmed et al. (2016) they found that statistical differences in sugar recovery percentage were recorded among the studied varieties.

It is clear that the sugar recovery percentage was significantly affected by the applied P-bio fertilizers levels. These is true in both seasons. It was noticed from results that the increasing the applied P-bio fertilizers application up to $600 \mathrm{~g} / \mathrm{fad}$ produced increment in sugar recovery values. This result is in partial agreement with that obtained by Muthukumaraswamy et al. (1994), Premono et al. (1995) and Ahmed (2013) who found that sugar recovery $\%$ was significantly affected by the applied P- bio fertilizer

TABLE 7. Sugar Recovery percentage of the three sugarcane varieties as affected by $P$-bio levels.

\begin{tabular}{|c|c|c|c|c|c|c|c|c|}
\hline \multirow{3}{*}{$\begin{array}{l}\text { Bio-P } \\
\text { fertilizer }\end{array}$} & \multicolumn{4}{|c|}{ Plant crop (2011/2012) } & \multicolumn{4}{|c|}{ First ratoon crop $(2012 / 2013)$} \\
\hline & \multicolumn{3}{|c|}{ Varieties } & \multirow[t]{2}{*}{ Mean } & \multicolumn{3}{|c|}{ Varieties } & \multirow[t]{2}{*}{ Mean } \\
\hline & $\begin{array}{c}\text { GT } \\
54-9\end{array}$ & G98-28 & G99-103 & & GT 54-9 & $\begin{array}{c}\text { G98- } \\
28\end{array}$ & $\begin{array}{c}\text { G99- } \\
103\end{array}$ & \\
\hline 200 & 10.71 & 10.80 & 10.41 & 10.64 & 10.71 & 10.70 & 10.17 & 10.53 \\
\hline 400 & 11.14 & 10.78 & 10.96 & 10.96 & 10.82 & 10.78 & 10.50 & 10.70 \\
\hline 600 & 11.93 & 11.12 & 11.20 & 11.42 & 12.10 & 11.08 & 10.76 & 11.31 \\
\hline Mean & 11.26 & 10.90 & 10.86 & & 11.21 & 10.85 & 10.48 & \\
\hline \multicolumn{9}{|l|}{ L S D $5 \%$ for: } \\
\hline Varieties $(\mathrm{V})$ & & & 0.35 & & & & & 0.33 \\
\hline P-biofertilizer (P) & & & $\begin{array}{l}0.47 \\
1.18\end{array}$ & & & & & $\begin{array}{l}0.41 \\
1.16\end{array}$ \\
\hline
\end{tabular}


Sugar recovery percentage was significantly affected by the interaction between studied factors. Sugar cane varieties G.T.54-9 recorded the highest sugar recovery percentage (11.93 and $12.10 \%)$ when supplied with $600 \mathrm{~g}$ P-bio fertilizer /fad in plant cane and first ratoon crops respectively.

\section{Sugar yield}

Data in Table 8 showed that the tested sugar cane varieties differed significantly in sugar yield in both seasons. Sugar cane variety G.99-103 surpassed G.T.54-9 and G.98-28 varieties by 0.057 and 0.448 tons of sugar/fad, in the plant cane crop. While in in the 1st ratoon crop sugarcane variety G.T.54-9 surpassed G.99-103 and G.9828 varieties by 0.055 and 0.592 ton/fad. This superiority of G.T.54-9 and G. 99-103 variety in sugar yield mainly attributed with the increase in recovery sugar and cane yield (Tables 7 and 4). The variation among sugar cane varieties in sugar yield has been reported by Mohamed et al. (2012), ElLabbody et al. (2011) and Ahmed et al. (2016) who reported that G.98-28 sugar cane variety recorded the highest sugar yields/fad in the plant cane and $1^{\text {st }}$ ratoon crops over the other two varieties.

Data in the same table showed that sugar yield was significantly increased as the level of P-bio fertilizer levels increased up to $600 \mathrm{~g} /$ fad this finding was true in both seasons. The highest value of sugar yield was obtained by using $600 \mathrm{~g} / \mathrm{fad}$ where it gave $(1.087-0.676 \mathrm{ton} / \mathrm{fad})$ and $(0.902$ -0.622 tons/fad) mor than levels of 200 and $400 \mathrm{~g} /$ fad in plant cane and $1^{\text {st }}$ ratoon crops, respectively. The increase in sugar yield may be due to increase of cane yield and better growth characters as mentioned before. Similar results were obtained by Premono et al. (1995), Shankara \& Nagariju (2000) and Ahmed (2013) who reported that inoculation by phosphorine significant influence on sugar yield.

TABLE 8. Sugaryield tons/fed. of the three sugarcane varieties as affected by P- bio levels.

\begin{tabular}{|c|c|c|c|c|c|c|c|c|}
\hline \multirow{3}{*}{$\begin{array}{l}\text { Bio-P } \\
\text { fertilizer } \\
\text { g/fad }\end{array}$} & \multicolumn{4}{|c|}{ Plant crop (2011/2012) } & \multicolumn{4}{|c|}{ First ratoon crop $(2012 / 2013)$} \\
\hline & \multicolumn{3}{|c|}{ Varieties } & \multirow{2}{*}{ Mean } & \multicolumn{3}{|c|}{ Varieties } & \multirow{2}{*}{ Mean } \\
\hline & $\begin{array}{l}\text { G.T. } \\
54-9\end{array}$ & G.98-28 & $\begin{array}{c}\text { G.99- } \\
103\end{array}$ & & G.T. 54-9 & $\begin{array}{c}\text { G.98- } \\
28\end{array}$ & $\begin{array}{c}\text { G.99- } \\
103\end{array}$ & \\
\hline 200 & 2.795 & 2.559 & 2.984 & 2.779 & 4.059 & 3.549 & 4.055 & 3.888 \\
\hline 400 & 3.398 & 2.811 & 3.361 & 3.190 & 4.147 & 3.924 & 4.434 & 4.168 \\
\hline 600 & 3.976 & 3.626 & 3.996 & 3.866 & 5.288 & 4.244 & 4.839 & 4.790 \\
\hline Mean & 3.390 & 2.999 & 3.447 & & 4.498 & 3.906 & 4.443 & \\
\hline \multicolumn{9}{|l|}{ L S D 5\% for: } \\
\hline Varieties (V) & & & 0.41 & & & & & 0.35 \\
\hline P-bio-fertilizer (P) & & & 0.48 & & & & & 0.44 \\
\hline (V) $\mathrm{x}(\mathrm{P})$ & & & 1.26 & & & & & 1.39 \\
\hline
\end{tabular}

Sugar yield significantly responded to the interaction between the two factors studied in the two seasons. The highest sugar yields (3.996 and 5.288 tons/fad) were obtained by inoculated G.99103 and G.T 54-9 variety with $600 \mathrm{~g} / \mathrm{fad}$ in the plant cane $1^{\text {st }}$ ratoon crops, respectively.

\section{Conclusion}

It could be concluded that under the conditions of the present work, it is recommended to inoculate G.99-103 or G.T 54-9 sugar cane varieties cuttings by $600 \mathrm{~g}$ P-bio fertilizer/fad to produce the highest cane, sugar yield. and decrease the environmental pollution.

\section{References}

Ahmed, A. M. (2013) Influence of bio phosphatic fertilizer on growth, yield and quality of three sugarcane varieties. Egypt. J. Appl. Sci. 28 (12B), 613-624.

Ahmed, A. Z., El-Bakry, A. and Abazied, Sakina R. (2016) Assessment of the optimum age for harvesting some promising sugar cane varieties. 
Minia J. Agric. Res. \& Develop. 36 (4), 635-651.

A. O. A. C. (1995) Association of Official Analytical Chemists. "Official Methods of Analysis," $16^{\text {th }}$ ed., A.O.A.C. International, Washington, D.C., USA.

El-Labbody, A.H.S.A., Osman, A.M.H. and Osman, M.S.H. (2011) Performance of two promising sugar cane varieties under different inter row spacing. $J$. Plant Production, Mansoura Univ. 2 (2), 297- 305.

El-Shafai, A.M.A. and Ismail, A.M.A. (2006) Effect of row spacing on yield and quality of some promising sugarcane varieties. Egypt J. Appl. Sci. 21 (11), 32-46.

Hebert, L. P. (1973) Testing of sugar cane varieties for milling quality. The Sugar J. 36 (4), 8-12.

Ismail, A.M.A., Hagrus, A.M., El-Sonbaty, M.M. and Farrag, S.A. (2000) Effect of phosphobacter in and phosphorus levels on yield and quality of sugar cane. Egypt. J. Agric. Res. 78(4), 1603-1613.

Kumaraswamy, K. and Rajasekaran, S. (1994)Response of sugar cane crop to nitrogen, phosphorus and biofertilizers. Cooperative Sugar, 26(2), 101-103.

Mathur, R. B. L. (1997) "Handbook of Cane Technology". Oxford IBH publishing Co. PVT. LTD New Delhi. Calcutta.

Mohamed, Kh. EM., Elwan, A.M. and Tawfik, Sahar F. (2012) The effect of cultivar and harvest time on yield and quality of sugar cane. Minia J. Agric. Res. Develop. 32 (5), 35-48.

Muthukumaraswamy, R., Revathi, G. and Solayappan, A. R. (1994): Biofertilizers a supplement or substitute for chemical nitrogen for sugar cane crop. Cooperative Sugar, 25 (7-8), 287-290.

Osman, A.M.H., El-Sayedm G.S., Osman, M.S.H. and Bekheit, M.A. (2004) Effect of plant density, mineral and biofertilizers of nitrogen and phosphours on sugar cane productivity. Egypt. J. Agric. Res. 82 (2), 697-716.

Premono, M.E., Anas, I., Soepardi, G., Tladioetomo, R.S., Saono, S. and Sisworo, W.H. (1995) Improvement of P uptake and growth of sugar cane by phosphate solubilizing microorganisms. Proc. ISSCT, 22, 268-274.

Rizk, T.Y., El-Agroudy, M.H., El-Geddawy, I.H. and Fergany, M.A. (2004) Effect of row spacing and cutting size on cane juice quality attributes. Egypt. J. Agric. Res. 82 (1), 251-262.

Shankaraih,C.,Hunsigi, G. and Nagariju, M. S. (2000) Effect of levels and sources of phosphorus and phosphate solubilizng microorganism on growth, yied and quality of sugarcane. Sugar-Tech. 2000,2: 1-2-28(C.F Record 617 of 1545-CAB Abstracts 2000/08-2001/07)

Snedecor, G.W. and Cochran, W.G. (1981) "Statistical Methods". Oxford and I.B.H. publishing G. $6^{\text {th }}$ ed., pp.299-310.

Steel, R.G.D. and Torrie, J.H. (1980) Principles and Procedures of Statistics." Mc Grow-Hill Book Co. Inc., New York.

Sundara, B., Natarajan, V. and Hari, K.(2001)Influence of phosphate solubilizing bacteria in soil available $\mathrm{P}$ status and sugar cane devolvement on a tropical vertisol. Inter. Soc. sugar cane Technolo. Proc. XXIV Congress, Brisbane, Australia, 17-21 Sep. 2: pp.47-51.

Yadav, R.L. and Sharma, R.K. (1980) Effect of nitrogen level and harvesting date on quality characteristics and yield of four sugar cane genotypes. Indian $J$. Agric. Sci. 50, 581-589.

Yousif, E.M.M., IbrahIm, M.M., El-Aref, A.O. A.O. Kh. and Ahamed, A. Z. (2015) Management of nitrogen fertilization for sugar cane on a sandy Soil: I yield and its components. Egypt. J. Appl. Sci. 30 (11), 498-511. 


\title{
استجابة ثلاثة أصناف قصب سكر للتسميد الحيوى الفوسفاتى
}

\author{
أحمد ذكى أحمد \\ معهذ بحوث المحاصيل السكررية ـ مركز البحوث الزر اعية ـ الجيزة ـ مصر.
}

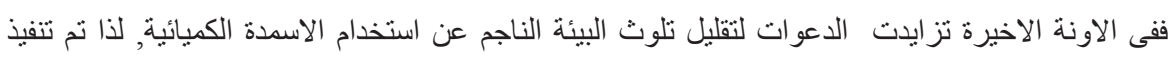

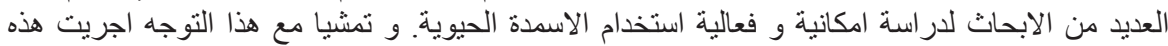

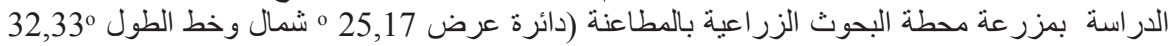

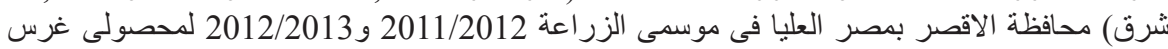

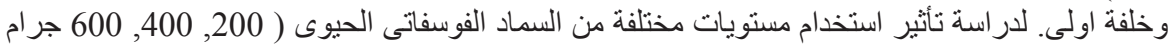

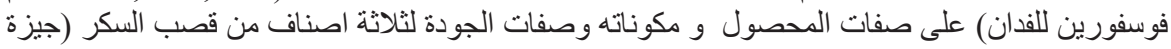

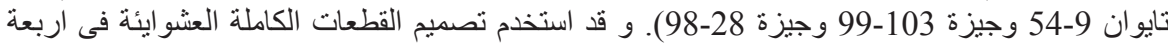

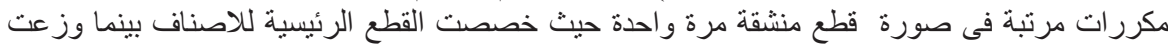

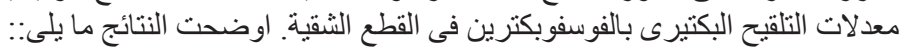

وجدت فروق معنوية فيما بين الاصناف محل الدر اسة , و قد أظهر الصنف المبشر جيزة 103-99 تفوقا

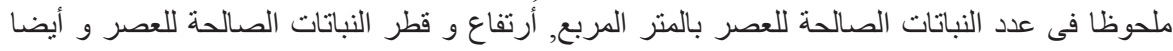

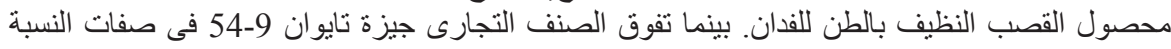

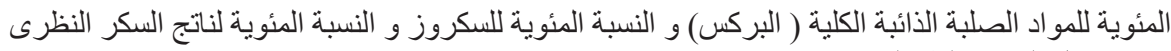
و محصول السكر بالطن لفدان.

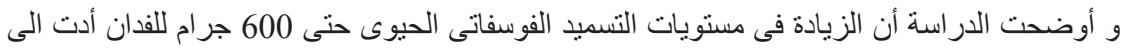

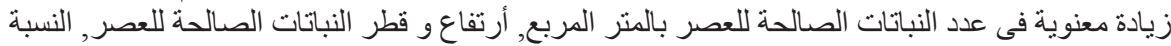

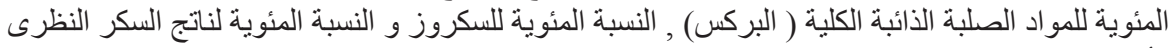
وأيضا محصولى القصب النظيف والية السكر بالطن للفدان.

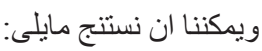

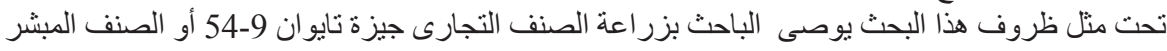

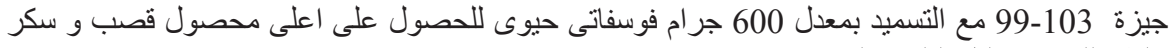
بالطن للفدن و تقليل التلوث البيئى. 